\title{
The Challenges of the Green Economy in Romania. Scientific Literature Review
}

\author{
Florin Mihai ${ }^{1, *} \mathbb{D}$, Ofelia Ema Aleca ${ }^{1} \mathbb{}$, Emilia Gogu ${ }^{2}$, Cosmin $_{\text {Dobrin }}{ }^{3}$ and Mirela Gheorghe ${ }^{1}$ \\ 1 Management Information Systems Department, Faculty of Accounting and Management Information \\ Systems, Bucharest University of Economic Studies, 010552 Bucuresti, Romania; \\ ofelia.aleca@cig.ase.ro (O.E.A.); mirela.gheorghe@cig.ase.ro (M.G.) \\ 2 Statistics and Econometrics Department, Faculty of Economic Cybernetics, Statistics and Informatics, \\ Bucharest University of Economic Studies, 010552 Bucuresti, Romania; emilia.gogu@csie.ase.ro \\ 3 Management Department, Faculty of Management, Bucharest University of Economic Studies, \\ 010552 Bucuresti, Romania; cosmin.dobrin@man.ase.ro \\ * Correspondence: florin.mihai@cig.ase.ro
}

Citation: Mihai, F.; Aleca, O.E.; Gogu, E.; Dobrin, C.; Gheorghe, M. The Challenges of the Green Economy in Romania. Scientific Literature Review. Sustainability 2021, 13, 13113. https://doi.org/10.3390/ su132313113

Academic Editor: Luigi Aldieri

Received: 18 October 2021

Accepted: 24 November 2021

Published: 26 November 2021

Publisher's Note: MDPI stays neutral with regard to jurisdictional claims in published maps and institutional affiliations.

Copyright: (c) 2021 by the authors. Licensee MDPI, Basel, Switzerland. This article is an open access article distributed under the terms and conditions of the Creative Commons Attribution (CC BY) license (https:// creativecommons.org/licenses/by/ $4.0 /)$.

\begin{abstract}
The goal of this paper is to conduct an analysis of the scientific literature on the green economy in Romania and to capture the main challenges in making the transition towards it. Despite the barriers and incomplete legislation, Romania has sufficient resources and the potential to increase the percentage of the green economy, especially as the UE offers incentives for aligning to European standards. An analysis of the scientific literature was conducted via exploratory research in the Scopus database, based on key topics within the thematic range of the green economy. The study focused on the one hand the depth of the research regarding these topics in Romania during the 2007-2021 period and on the other hand, an analysis of the existence of possible links between these topics. The connections between the topics were analyzed through nine hypotheses. The results obtained reveal the researchers' concerns for the way the principles of the green economy are applied in Romania and the existing correlations between these analyzed topics and how they are reflected in the economic reality. These results can represent a starting point as regards the diversification of policies and measures aimed at improving the implementation of the principles of the green economy in Romania.
\end{abstract}

Keywords: green economy; waste management; green technology; carbon emissions; social inclusion; rational consumption; Romania

\section{Introduction}

Interest in the green economy arose when the financial crisis started in 2008, when investments in the green economy sectors were seen as a means both for reestablishing economic growth, and for coping with the degradation of the environment. Most governments adopted a form of green economy based on "clean technologies" that involved using renewable energy and production methods generating low carbon emissions and minimum consumption of natural resources. Nevertheless, this approach was criticized as well for not always succeeding in tackling genuine environmental issues and for not doing anything to reduce social injustice, inequity and poverty [1]. At present, environmental protection is a priority worldwide, the green economy being the result of a process that may reduce inequality, the deficit of resources and environmental risks [2]. In this context, the most used words are "sustainable" and "green". Many times, they are used as if they were synonymous, however, the green economy describes the road to sustainability [2]. Sustainable development aims to satisfy the current needs of society, without compromising the possibility for future generations to satisfy their own needs [3]. Other authors [4-7] believe that the green economy, circular economy and bioeconomy can be understood as fulfilling more of an auxiliary role than a substitute for sustainable development. 
The research aims to contribute to the debate on the topic of the green economy, raising a few topics of interest regarding the way in which the particulars of each country, specifically Romania, may influence the implementation of the principles of sustainability.

\section{Literature Review}

Until the emergence of the concept of green economy and those associated with it (sustainability, durability), all the sectors of an economy used to function as if all natural resources used were inexhaustible. The unprecedented economic growth of the 20th century and certain climate changes have caused certain researchers to find that certain natural resources are getting depleted faster than others and certain industrial processes produce substance emissions that influence the local climate or even the global climate.

Part of the natural resources are able to regenerate naturally, on condition that they are exploited reasonably, others are just used up with no ability to regenerate. Thus, the idea of rational, reasonable exploitation came about, the concern for future generations, without endangering nature and its ecosystems. Then, certain resources were considered dangerous for the environment and the idea of reducing and then stopping their use was adopted.

In 1972, a report of the Club of Rome first introduced in a paper titled "The Limits to Growth" the idea that some important natural resources are getting depleted fast. This represents a milestone in the context of the concerns for ensuring a sustainable economy.

The concept of the green economy is relatively recent and was first coined at the end of the 1980s by [8] and popularized in a report known as Plan for a green economy. This report was drawn up for the government of Great Britain, after which it was overlooked for some time, and only came back to the foreground in 2008 when the United Nations Environment Programme (UNEP) launched the Green Economy Initiative. This initiative offers support for research and aid in the area of green investments, to clean the sectors that are in breach of environmental policies, being a means of achieving sustainable development. After the United Nations Conference (UN) in Rio in 2012, the definition of the green economy was improved upon, being considered inclusive green economy. According to UNEP: "A green economy is one which results in improved human well-being and social equity, while significantly reducing environmental risks and ecological scarcities".

It is generally accepted that a green economy implies protecting the environment by using renewable resources, reducing the consumption of hydrocarbons and organic farming. Most endorsers of the green economy believe that the economy is part of the environment and support the idea that it must include a peaceful interaction between the people and the environment so that the needs of both categories are satisfied.

Using renewable resources is one of the basic objectives of the green economy, together with reducing emissions, considered toxic for the environment. In addition to promoting clean energy, with reduced emissions and zero carbon emissions, the green economy takes into account that ecological processes occurring in natural and semi-natural systems can be used for the benefit of the people without endangering the sustainability of these ecosystems [7].

All existing processes and infrastructures that are essential for human activities represent an economic system (Europa.EU). The economy and the society operate as interconnected subsystems of the biosphere, sustainability is associated with high durability [9]. Durability represents the period during which goods can be used. Sustainability represents the property of goods to last as long as possible over time [10]. High durability of goods will reduce the pressure on society and, implicitly, increase sustainability, efficient and intelligent use of resources, increasing their ability to re-generate. Low durability shall put more pressure on society and the environment, leading to a decrease in the efficiency of resource utilization and even faster depletion of certain resources.

Beneficial ecologic processes and ecosystem services support to a large degree the operation of our economy and society but are often invisible or ignored. Ecological activities include solutions for "reducing carbon emissions and pollution, increasing energy and 
resource efficiency and preventing the loss of biodiversity and ecosystem services" [2]. The guidelines for increasing sustainability in the context of the green economy include [11]:

- Investments in non-fossil fuels and efficient energy production

- $\quad$ Giving up subsidies for fossil fuels

- Developing best practices for managing unsustainable land

- Managing the price of natural resources

- Including the price of carbon or water

- Tax on carbon emissions

- Projects to capture and store the carbon resulting from inevitable emissions

- Payments or compensations for ecosystem services.

Increased importance is given to regulations regarding the policies on investments/disinvestments, taxes, incentives, payments and compensations, as well as to aspects related to certification and standardization $[4,6]$. It is a known fact that regulations had a slower debut and evolution, in the beginning, many of the objectives of the green economy were sometimes used for political gain. Currently, concerns around regulation are very serious, the European Parliament adopting on the 14th of July 2021 several proposals (Europa.EU) to adapt EU policies in the areas of climate, energy, transportation and taxation in order to reduce net greenhouse gas emissions by at least $55 \%$ until 2030, relative to the values in 1990.

The green economy includes certain elements of the circular economy, such as reducing the consumption of materials and energy in the production process, recycling and reuse, more sustainable supply chains. The circular economy gains increasingly more attention both in the EU and worldwide, as a potential path for raising prosperity while also reducing the dependency on natural finite resources and on energy [12]. The circular economy means that in an economic cycle everything is designed in such a way that all the components of a product or process are biodegradable or are potentially $100 \%$ recyclable or reprocessable [13]. The implications of implementing a circular economy are very big both from an economic and social view, as it calls for a specific strategy to be developed. In this regard, it is clear that without a particular motivation, citizens and enterprises can be hesitant to implement certain activities that can minimize the impact on the environment [14]. As regards Romania, in 2015, the circular material use rate was 1.5\% compared to the EU average of $11.7 \%$ [15]. By the strategy proposed through [16], Romania has set as a target to transition to a circular economy using complementary approaches that involve traditional methods and state of the art technologies in order to re-establish/recreate the natural capital and reduce the dependency on synthetic fertilizers and pesticides and to counteract soil degradation.

Table 1 synthesizes the main objectives of the European Union concerning issues related to the green economy and Romania's main objectives and programs in this direction.

Table 1. EU and Romania's objectives for the green economy.

\begin{tabular}{|c|c|}
\hline Objectives and Targets of the European Union & Programs and Objectives for Romania \\
\hline \multicolumn{2}{|l|}{ Waste management } \\
\hline \multicolumn{2}{|l|}{$\begin{array}{l}\text { Since 2016, the rate minimum level for the collection of waste } \\
\text { electrical and electronic equipment (WEEE) is } 45 \%\end{array}$} \\
\hline \multicolumn{2}{|l|}{$\begin{array}{l}\text { (EU Directive on waste electrical and electronic equipment } \\
\text { (WEEE)) [17] }\end{array}$} \\
\hline \multicolumn{2}{|l|}{ By 2025 , at least $55 \%$ of municipal waste must be recycled. } \\
\hline $\begin{array}{l}\text { Between } 2025-2030 \text {, at least } 60 \% \text { of municipal waste must } \\
\text { be recycled }\end{array}$ & Starting with 01.07 .2021 , Romania enforced the obligation to \\
\hline By 2035 , at least $65 \%$ of municipal waste must & selectively collect residential waste [19]. \\
\hline be recycled & \\
\hline (EU Waste Framework Directive) [18] & \\
\hline
\end{tabular}


Table 1. Cont.

Objectives and Targets of the European Union
By 31 December 2025, at least $65 \%$ of the weight of all pack
must be recycled.
By 31 December 2030, at least $70 \%$ of the weight of all pack
must be recycled.
(EU Directive on packaging and packaging waste) [20,21]
Carbon emissions
Reducing the $\mathrm{CO}_{2}$ emissions of new cars and vans [22]:
- $55 \%$ reduction of emissions from cars by 2030
- $50 \%$ reduction of emissions from vans by 2030
- $\quad 0$ emissions from new cars by 2035

Carbon uptake by afforestation [25][A]

$268 \mathrm{Mt}$ current carbon removals

Green technology

Renovation of building:

renovate at least $3 \%$ of the total floor area of all public buildings annually [25] set a benchmark of $49 \%$ of renewables in buildings by 2030 [25]

Energy efficiency:

- $40 \%$ new renewable energy target for 2030 [25] 6-39\% new 2030 energy efficiency targets for final and primary energy consumption [25] increase the use of renewable energy in heating and cooling by +1.1 percentage points each year, until 2030 [25]

UE Eco-innovation Action Plan [31]:

- integration of eco-innovation in environmental and industrial policies

- financing eco-innovation projects

- $\quad$ adoption of eco-innovation in the private sector

- $\quad$ the workforce has the appropriate skills and knowledge to promote the transition to the green economy

Social inclusion

- $\quad 35$ million buildings could be renovated by 2030 [25] 160,000 additional green jobs could be created in the construction sector by 2030 [25] improving health services

- $\quad$ help vulnerable categories

- movement of at least 20 million people from the at-risk-of-poverty area (Europe 2020)

Rational consumption

Improve health and wellbeing [25] A new Circular Economy Action Plan [33]

New consumer agenda that will lay out the priorities for EU consumer policy up to 2024 [34]
Programs and Objectives for Romania

$70 \%$ recycling of packaging waste as well as separate collection of hazardous household waste by 2022, bio-waste by 2023 and textiles by 2025 [16]

Reducing emissions by 2030 by $2 \%$ compared to 2005 [15]. In the period 2016-2019, funds were allocated for the establishment of recharging stations for electric vehicles in localities (EUR 19 million) [23]

In 2018, funds were allocated for the purchase of less polluting vehicles in local public passenger transport (EUR 92 million) [24]

Increasing the capacity of forests carbon storage in the context of a sustainable forest management; the creation carbon stock recovery framework [26]

2020, a new program for buildings renovation (EUR 86 million) [27]

2021, a new program for public buildings

(EUR 280 million) [28]

2010-2017, the program on the installation of heating systems using renewable energy (EUR 36 million) [29] Starting with 2019, the photovoltaic green house program [30]

Romania ranks 23rd on eco-innovation with 65 points compared to the EU eco-innovation index of 100 points [15]

The number of people employed in the circular economy in 2016 in Romania was $1.54 \%$ of the total employed population compared to the EU average which was 1.73\% 2014-2020, Romania planned $100 \%$ of the funds allocated by the EU for social inclusion and spent $51 \%$ of them [32]

Halving per capita, by 2030, food waste at retail and consumption level and reducing food losses along production and supply chains, including post-harvest losses [16]

A study on attractiveness conducted by EY in 2021 [35] considers that Romania is attractive in terms of the investments in the green economy, benefiting from the opportunities offered by the European Green Deal and the Just Transition Mechanism, but also from other funds targeting the green economy: the Recovery and Resilience Facility, the Innovation Fund, the Modernisation Fund. 
According to some authors $[36,37]$ who promote ideological elements related to sociocracy, a green economy would even include common property over capital goods, lands, etc., but we believe such aspects pertain to a rather socio-political debate.

Economic actors may be reluctant to become financially involved in environmental projects [38] due to low profitability or if it can only be obtained by very high financial efforts. Lack of interest in environmental projects may also be caused by a lack of regulation or of political will, as in a lot of cases many of the objectives of the green economy remain mere statements [39]. Other authors [40] have also found that without a satisfactory level of potential profitability, regulations or efficient intervention or investments in education, companies are quite reluctant to adopt environmental policies. A means to encourage the development of the green economy is to grant incentives for the development of projects that are beneficial for the environment and to impose sanctions when environmental policies are breached, respectively to educate towards responsibility. There are many countries that resort to these methods, but their efficiency is influenced by the issue of credibility in the eyes of the beneficiaries [41].

Some authors [6] have also identified limitations of the green economy, including aspects related to the necessity of adopting certain technological solutions, which are sometimes quite advanced and costly, and which, in relation to the obtained goods that can be marketed based on market rules, are considered insufficient to cope with the current sustainability issues and are sometimes identified as a cause for the emergence of other problems that end up affecting the environment. In order to reduce the effects of this limitation, it is necessary to increase the level of environmental education of citizens, combined with an ever-increasing involvement in green jobs.

As regards the green economy, Romania has vast healthy agricultural land, many employees, but lower education levels, low count of machinery, agricultural taxes, etc. [42]. According to Eurostat 2019, Romania is one of the European countries that could become an agricultural producing country with well-paid employees, appropriate training programs for managers and employees in the agricultural sector. Furthermore, more investments in agriculture and green economy are needed [42] to reduce environmental costs [43].

A barrier for organizations in promoting environmental practices is the fact that the company management does not adopt formal regulations in this field. Big-size organizations however are more concerned with these issues and the chances of adopting management systems for environmental protection are much higher [43]. Some of the best practices identified by [44] that can be used by company managers for the implementation of certain principles of the green economy: recycling, to the extent that there are recyclable products (upcycling), using equipment beyond the accounting depreciation time, using personal items or equipment for professional purpose in order to limit the consumption and recovering waste, collective use of printers and copiers, as well as using recycled paper; lighting or heating equipment with reduced energy consumption; shutting off plants and equipment using energy when paused; digitizing archives and databases, selective waste collection; collaborating with external suppliers or consult-ants for waste management; and supporting environmental NGOs, using green vehicles. However, we believe that some of these practices that could be promoted require additional regulation by the organizations or at least increased attention, such as the use of personal items or equipment for professional purposes or the use of equipment be-yond the accounting depreciation time. It is possible that some such equipment could cause more environmental pollution than buying new ones (for instance a very old but still operational truck).

Based on the analysis of the literature on the concept of green economy, we have identified the main topics of interest associated with it:

1. Waste management

2. Reducing carbon emissions

3. Green technology

4. Social inclusion

5. Rational consumption 
Waste management

Waste is one of the main issues that countries face in their efforts to counteract pollution. Appropriate waste management presupposes the existence of a legislative framework that establishes a series of rules regarding efficient waste management. Waste management refers to all the activities of collection, transport, treatment, recycling, and storage of waste. Its objective is to reduce the effect of waste on the health of the people, of the environment, as well as to save natural resources by reusing recoverable elements.

Parts of electrical and electronic equipment (EEE) that are discarded without being reused are called e-waste or waste electrical and electronic equipment (WEEE). This is an important part of the elements that can be reused. Worldwide, $45 \mathrm{mt}$ of WEEE were disposed of in 2016 (only 20\% were officially recycled), and $52.2 \mathrm{Mt}$ are expected to be disposed of by 2021 [45].

Regulations specific to WEEE target the improvement of the collection of recyclable materials. However, most WEEE regulations seem to be ineffective, and inadequate processing of electrical and electronic equipment has dangerous effects on human and environmental health. A sustainable WEEE management system should be able to process $100 \%$ of electronic waste, to recover recyclable materials, to separate dangerous components, to support economic development and create jobs [46].

As a member of the European Union, Romania has undertaken to establish a national framework to support the 2030 Agenda for Sustainable Development and has set a target for 2030 to recycle $70 \%$ of its packaging waste, as well as the separate collection of domestic hazardous waste by 2022, of biological waste by 2023 and of textiles by 2025 [16].

The Environmental Implementation Review 2019 [15] shows that waste management is still a major challenge for Romania, despite the formal progress registered as a result of adopting the national waste management plan in December of 2017. Recycling and efficient use of resources are still at low levels when compared to the trend presented in the 2017 report. Romania had in 2019 a municipal waste recycling rate of 12 compared to 67, the highest rate in the EU (Germany) [47]. Starting with 01.07.2021, Romania enforced the obligation to selectively collect residential waste [19].

Reduction of carbon emissions

Increasing carbon emissions and the connection to economic progress and energy are considered very important in the debate on climate change, as both economic growth and energy consumption are regarded as the main factors for environmental degradation [46,48]. Thus, mediating between growth and the environment has become a key challenge for political decision-makers in the development of a balanced strategy for economic growth Given that conventional energy (fossil fuel) is regarded as the main source of carbon emissions, the development of a zero-emissions economy, while the demand for energy is growing, entails high financial commitment and social responsibilities [48-50]. Investments in clean energy promote economic growth, while at the same time reducing the carbon emissions of the energy industry and stabilizing total greenhouse gas emissions in the energy sector [51]. In order to achieve its objectives in the area of climate, the European Union has drawn up an ambitious law [52] including:

- An emissions trading scheme for emission allowances for the industry

- Carbon tax on imported goods

- Solutions for reducing carbon dioxide emissions in other sectors

- Increasing wooded land

- $\quad$ Reducing car emissions

The European Parliament has set as objectives for the entire European Union (Europa.EU) the reduction of net greenhouse gas emissions produced by passenger cars by at least $55 \%$ by 2030, relative to the values in 1990, and zero emissions for new passenger cars by 2035. According to the European Green Deal [25], the general objective of the European Union is to reach zero greenhouse gas emissions by the year 2050. As regards the energy obtained from renewable resources, the EU has set the objective of reaching a $40 \%$ quota of the total by 2030 . The Romanian state has taken steps in the direction of 
reducing carbon emissions when producing electricity and offers each year subsidies for installing photovoltaic panels through the photovoltaic greenhouse program [30] and other programs to stimulate the renewal of the car fleet.

It is certain that measures to overtax emission-generating industrial processes or taxing imported goods are political and economic decisions that, if exaggerated, may generate very big price increases for goods and services, which, in turn, may be the cause of social unrest. In the end, social unrest may result in changing the ruling class with one that is more lenient on pollution and the resulting effect will be the opposite of the desired one.

Green technology

Automating and digitalizing processes in the green economy envision the use of technologies that are not harmful to the environment in all the stages of the development cycle of goods and services. A definite role in this enterprise is given to digitalization through software that optimizes production processes starting from before their commencement, as well as after production as such is finished, in order to ensure the circular principles of the green economy. Among the latest technologies that can be used is blockchain technology, which provides the digital infrastructure for a wide range of applications that can even lend themselves to sustainable development [53]. Blockchain platforms for decentralizing renewable energy networks were developed, including platforms for alternative food production networks [54] and environmental monitoring. Other authors [55] have identified the potential for blockchain technology use in land registers and supply chains.

It is worth mentioning that platforms based on blockchain technology using concepts associated with the green economy, which also offer the possibility of implementing "universal basic income" schemes have become increasingly popular. The author of [56] considers that due to the lack of any regulation, these could still start behaving like a genuine trojan horse. Along the same line, communities promoting concepts of the green or circular economy, using virtual currency based on blockchain technology as a payment method recognized only within the community or for remunerating certain activities inside the community were also developed. One such platform is SEEDS who, under the motto "we reward the regeneration of the planet instead of being more profitable", uses special algorithms and its own financial system to stimulate collaborative and regenerative behaviors and activities [57]. Biotechnologies as part of the bioeconomy point to another direction towards the development of traditional agricultural, forestry and animal husbandry technology, without the use of stimulant chemicals [58]. Strategic actions related to the bioeconomy must ensure coherent investment programs in research, innovation and skills provision, the integration of policies in the field with the commitment of stakeholders, the improvement of the competitive environment and markets.

Small and medium-sized companies as an engine for economic development are dependent to a large extent on the regulatory framework and the environmental protection law, meaning that the integration of green technologies in their activities should determine an increase in the efficiency of their operations. They can be hesitant to adopt certain environmental management systems (EMS) due to the lack of any aid or awareness [59]. An environmental management system is a very important tool that should be integrated within environmental protection policies and other policies aimed at obtaining a sustainable model for production and consumption [60]. Eco-innovation plays a very important part in the integration of green technologies and dates back to one of the key aspects of EMS: the principle of continuous improvement of performance. The more an EMS is comprehensive, the higher the performance in terms of stimulating technological innovation [61].

Ref. [15] shows that in the European ranking on eco-innovation Romania takes 23rd place with 65 points compared to the EU eco-innovation index totaling 100 points. The market prices do not accurately reflect the environmental costs and benefits, the rigid economic structures and the precarious infrastructure being the main issues affecting eco-innovation [31]. 
Social inclusion

Generally speaking, the process of social inclusion represents the ensemble of measures and actions in the fields of social protection services, employment, housing, education, health, information, communication, mobility, security, justice and culture, meant to fight social exclusion and ensure active participation of the people in all eco-nomic, social, cultural and political aspects of the society [62]. As shown previously, the green economy aims to be socially inclusive. One of the major factors influencing social inclusion in the green economy is digitalization. Digitalization of the processes in the green economy entails risks of social exclusion, systemic instability and even data security risks [63]. Therefore, it must be evaluated thoroughly from all perspectives in terms of the benefits and risks for the green economy.

An important role in social inclusion is played by human creativity [64-66]. This is essential in the development of certain innovative methods for designing clean products so that they are easily dismantled, recycled, consume less energy and have a smaller carbon footprint.

According to [15] the percentage of people engaged in the circular economy in 2016 in Romania was $1.54 \%$ of the total of the people employed versus the EU average of $1.73 \%$, which is a relatively small percentage when compared to the final target of the European countries of migrating to the circular economy.

Rational consumption

Resources such as water, soil, clean air and ecosystem services are vital for health and for the quality of life but are available only in limited supply [67]. Resources must be managed more efficiently during the whole lifecycle, from extraction, transport, processing, and consumption until waste disposal. This is the reason why the Commission insists on "effective use of resources". Effective use of resources means producing more value with fewer resources and changing consumption habits. This will limit the risk of emerging deficits and shall maintain the impact on the environment within the natural limits of the planet [67]. The way we use resources must offer them the possibility of natural or seminatural regeneration. Over the last years, there is a greater awareness of environmental issues associated with consumer habits and the behavior of European citizens tends to become positive in terms of the use of resources [68].

The target proposed by Romania for 2030, as a member of the European Union, is to halve the food waste per capita at retail sale and consumption level and to reduce food loss down the manufacturing and supply chains, including post-harvesting losses [16].

\section{Research Methodology}

This research aimed at contributing to the debate about the challenges of the green economy in terms of waste management, reducing emissions, green technology, social inclusion, and rational consumption, raises certain topics of discussion regarding the interest of the scientific research community in Romania in the field of the green economy. Last but not least, it is an invitation to reconsider lesser-known aspects of the issues of the green economy. The goal we set was to provide a description of a few considerations on the challenges that Romania is facing in adopting and implementing the principles of the green economy, as well as the implications for the society at large.

The research we propose is an exploratory study of the scientific literature approaching topics related to the green economy in Romania starting with 2007 until 2021. We believe that the subject has not been researched sufficiently before in the literature, similar concerns were shown by the authors of article [40] regarding the analysis of the scientific literature on the green economy in Slovenia, Croatia, Serbia and Bosnia and Herzegovina.

The research methodology used takes into account the opinion expressed by [69] proposing a research methodology consisting of three phases. The first phase for collecting the research material, the second phase offers a thorough descriptive revision of the articles collected, while the third phase extrapolates the collected information and summarizes the conclusions. First of all, the data was collected by interrogating the Scopus database 
based on a set of key topics considered relevant for the research subject chosen and for Romania. The Scopus database was interrogated in September of 2021, then an analysis of the content of the selected articles was conducted based on the key topics selected and the existence of any connections between them was analyzed, from a statistical correlation point of view. At the end, the limits of the research, the main directions for expanding it and the final conclusions were presented.

Apart from analyzing the scientific impact of any key topic considered by the research carried out, based on the analysis of the literature in the field and the fact that technologies are a key element within the green economy, research hypotheses were also formulated regarding the possible interdependence between particular topics:

Hypothesis $\mathbf{1}$ (H1). There is an interdependence between "green technology" and "carbon emissions".

The reduction of carbon emissions as a goal of the green economy leads to the development of technologies in the energy field and that of biotechnologies.

Hypothesis 2 (H2). There is an interdependence between "green technology" and "waste management".

The issue of waste management is an important part of the transition to the green economy and can be easily handled by means of digitalization and of technological innovations. Using dedicated platforms, we can trace parts of electrical and electronic equipment in order to recycle and reuse components.

Hypothesis $\mathbf{3}$ (H3). There is an interdependence between "green technology" and "rational consumption".

Rational consumption is greatly influenced by the information that consumers get, but also by the technologies available to them. Rational consumption can be a wild card for the use of green technologies, which may be more expensive and not as economically efficient as some classical technologies based on polluting elements, at least not in the early stages. Integrated information systems can support consumers in identifying the best and most practical solutions for rational consumption.

Hypothesis 4 (H4). There is an interdependence between "green technology" and "social inclusion".

The increase of knowledge about technology and computers, telework, the digitalization of certain public services and many others may jeopardize social inclusion, especially that of vulnerable individuals.

Hypothesis 5 (H5). There is an interdependence between "carbon emissions" and "social inclusion".

The reduction of carbon emissions as a result of using innovative technologies may cause certain jobs to disappear. Social inclusion entails the implementation of protective measures, especially for certain vulnerable categories.

Hypothesis 6 (H6). There is an interdependence between "carbon emissions" and "waste management".

Efficient waste management may lead to the reduction of carbon emissions due to recycling and reuse.

Hypothesis 7 (H7). There is an interdependence between "waste management" and "social inclusion".

Human creativity has an important role in terms of social inclusion [64-66], being essential in finding new innovative methods to design green products in a way that 
makes them easy to dismantle and recycle, consume less energy, and have a smaller ecological footprint.

Hypothesis 8 (H8). There is an interdependence between "rational consumption" and "social inclusion".

Rational consumption will keep the impact on the environment within the natural limits of the planet [67], an influencing factor being the way it is perceived by consumers. Certain vulnerable categories may have little interest in certain product categories due to their price or the impossibility of accessing certain information for lack of Internet connectivity.

Hypothesis 9 (H9). There is an interdependence between "rational consumption" and "waste management".

The increase of individual consumption during the epidemic has led to an increase in the waste volume, and in particular instances, due to working from home, we have seen a transfer of the waste management issues from the organizations to the employees.

\section{Data Analysis}

In the data analysis stage, we consider the key topics used by scientific papers in Romania in order to estimate the scientific concerns regarding the green economy. After data collection, the articles resulting from the interrogation of the Scopus database were analyzed, and at the end, the conclusions were drawn.

The selected articles were identified within the Scopus database based on the key topics established when the research model was formulated. Using descriptive statistics, the key topics used for selecting the articles that fall under the scope of the research, as well as the distribution over time of the selected articles are presented in Table 2.

Table 2. Distribution of the research articles in Romania per topic in the period 2007-2021.

\begin{tabular}{|c|c|c|c|c|c|c|c|c|c|c|c|c|c|c|c|c|}
\hline & 2007 & 2008 & 2009 & 2010 & 2011 & 2012 & 2013 & 2014 & 2015 & 2016 & 2017 & 2018 & 2019 & 2020 & 2021 & Total \\
\hline $\begin{array}{l}\text { Waste } \\
\text { management }\end{array}$ & 8 & 16 & 20 & 30 & 20 & 33 & 34 & 29 & 23 & 29 & 26 & 35 & 35 & 19 & 15 & 372 \\
\hline $\begin{array}{l}\text { Green } \\
\text { technology }\end{array}$ & 0 & 0 & 3 & 3 & 2 & 7 & 6 & 3 & 2 & 1 & 10 & 16 & 6 & 4 & 5 & 68 \\
\hline $\begin{array}{l}\text { Carbon } \\
\text { emissions }\end{array}$ & 2 & 7 & 11 & 5 & 7 & 15 & 18 & 13 & 10 & 12 & 20 & 22 & 21 & 15 & 18 & 196 \\
\hline Social inclusion & 2 & 3 & 6 & 4 & 8 & 6 & 7 & 13 & 14 & 8 & 13 & 10 & 7 & 8 & 12 & 121 \\
\hline $\begin{array}{l}\text { Rational } \\
\text { consumption }\end{array}$ & 0 & 0 & 0 & 1 & 0 & 0 & 4 & 1 & 3 & 2 & 1 & 1 & 1 & 0 & 1 & 15 \\
\hline Total & 12 & 26 & 40 & 43 & 37 & 61 & 69 & 59 & 52 & 52 & 70 & 84 & 70 & 46 & 51 & 772 \\
\hline
\end{tabular}

The distribution of articles considered in this research over time reveals that massive interest in the researched topic in Romania can be noticed especially after 2016 (Figure 1).

From the articles that were found, most are from 2018, a large proportion of these dealing with the "waste management" topic (Figures 1 and 2). In 2013 there were 69 articles $(9.08 \%)$, of which 34 are focused on "waste management". This aspect reveals that concerns in the area of the green economy appeared relatively early when compared to the moment of the "emergence" of the concept of the green economy.

An explanation for the smaller number of articles in 2020 focusing on topics of the green economy as research objects may be the COVID-19 pandemic, which has limited and changed a great deal of the activities taking place, including those in the area of science and of the green economy. Certain scientific research in the field of the green economy may entail onsite travel, however, this was significantly limited in 2020, due to the COVID-19 pandemic. The number of articles on this topic in 2020 was 46, surpassing noticeably only those from the year 2011, when 37 articles were written. As a result, we can state that scientific production was also severely impacted by the COVID-19 pandemic. 


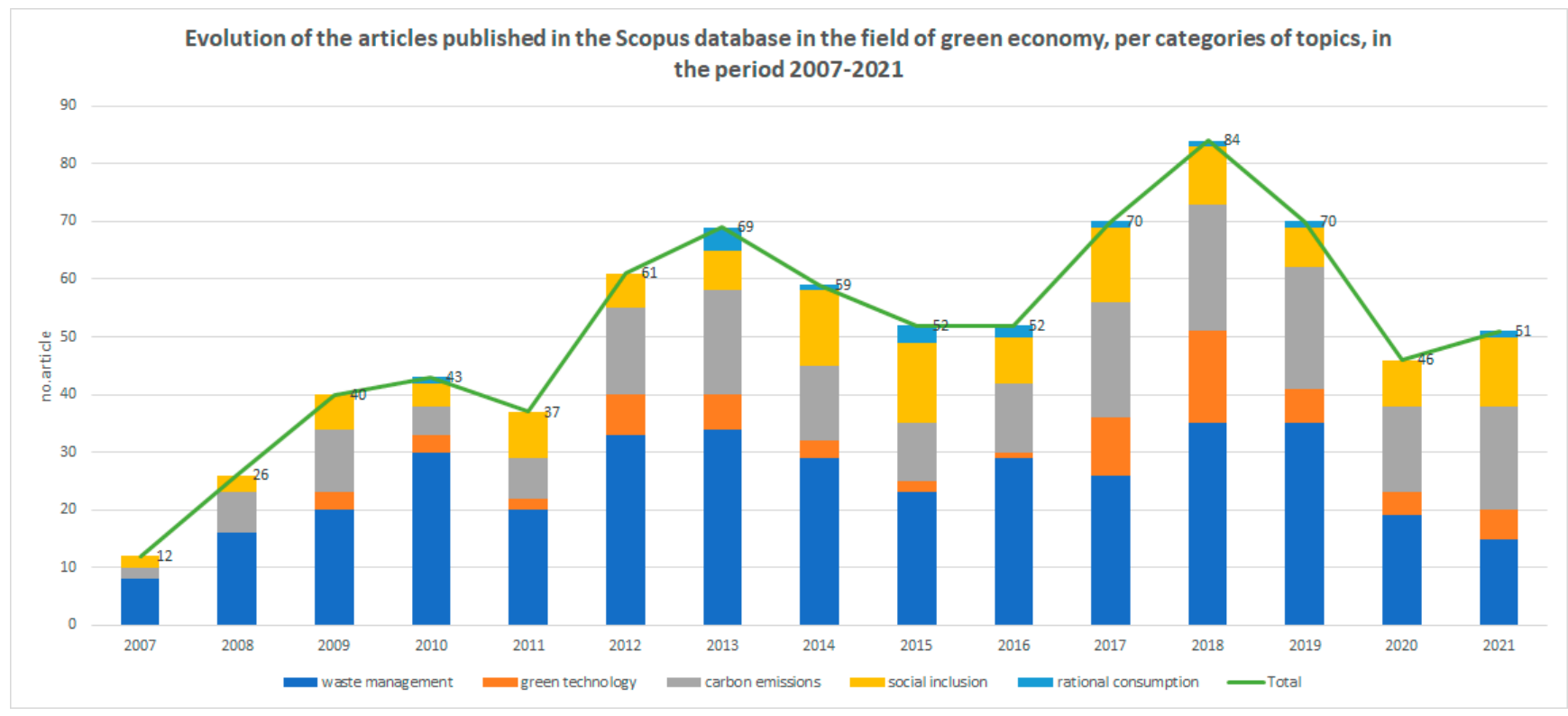

Figure 1. Evolution of the articles published in the Scopus database in the field of green economy, per categories of topics, in the period 2007-2021. Source: processing done by the authors, based on the data interrogated in the Scopus database.

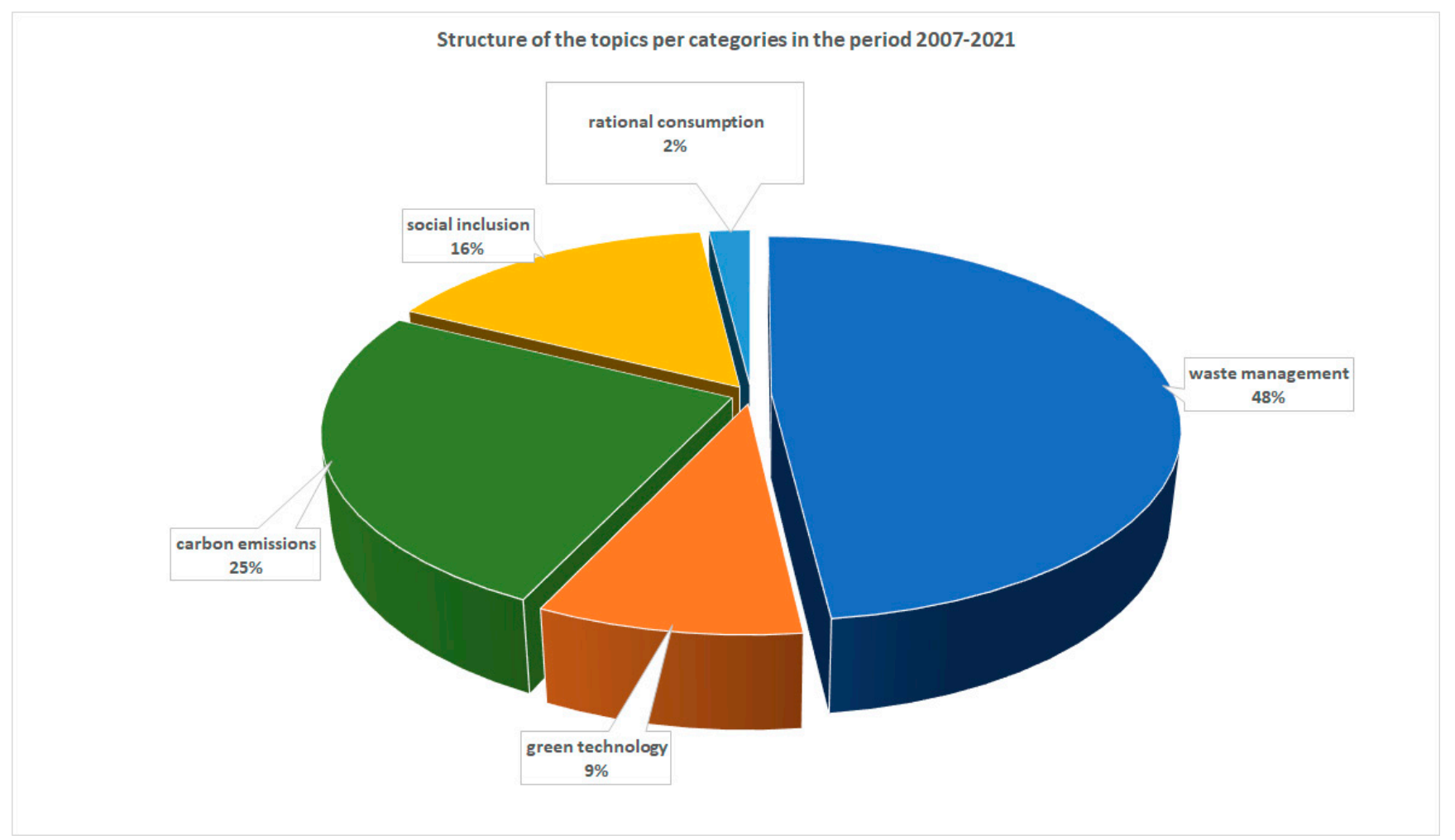

Figure 2. Structure of the topics per category in the period 2007-2021. Source: processing done by the authors, based on the data interrogated in the Scopus database.

Waste management in Romania

Scientific interest in the field of waste management is great, 372 papers were found when searching for the topic "waste management Romania", most of them from the period 2018-2019. For the year 2020, we found 19 scientific articles on this topic, which is also a decrease from 2019, the reason being the COVID-19 pandemic. The year with a lower scientific output than 2020 was 2008 when only 16 articles were written. 
The scientific papers dealing with topics related to waste management in Romania have identified several challenges and potential problems in this regard, synthesized under Table 3.

Table 3. Synthesis of the main challenges and potential problems identified in waste management in Romania.

\begin{tabular}{ll}
\hline Topics & Challenges and Potential Problems \\
\hline Digitalization platforms & $\begin{array}{l}\text { Flawed monitoring of the waste management infrastructure; an effect of this is the } \\
\text { difficult recording of the management of the specific quotas for product recycling }\end{array}$ \\
Selective waste collection & $\begin{array}{l}\text { Very low collection rate for waste and electronic equipment } \\
\text { Wastewater treatment plants can cause outbreaks and spread germs (antibiotic-resistant } \\
\text { bacteria, etc.) }\end{array}$ \\
The COVID-19 pandemic & $\begin{array}{l}\text { The transfer of a part of the waste management responsibility from organizations to the } \\
\text { employees in the context of working from home } \\
\text { Change in consumer behavior and in the quantity of waste produced }\end{array}$ \\
\hline
\end{tabular}

After the accession to the EU, Romania had to put in a great deal of effort to implement waste management by adopting European directives or by transposing them into the national law. Consequently, private or state-owned companies involved in the sale of various categories of goods must pay attention to waste collection and observe specific recycling targets. One of the significant issues in Romania is that there are no software platforms that offer the necessary digitalization for companies concerned with environmental protection [70]. Nevertheless, [71] proposed as early as 2015 designing a web platform dedicated to monitoring the green infrastructure in Bucharest, Romania.

The COVID-19 pandemic and the subsequent blockages have led to changes in consumer behaviors, not only regarding the buying patterns but also regarding the quantity of waste produced [72]. Among the issues identified in Romania [46] are the very low collection rate for waste electrical and electronic equipment and the almost non-existent reuse rate. Therefore, according to [15], in Romania, the general recycling rate of municipal waste is $14 \%$, which comprises $7 \%$ material recycling and $7 \%$ composting.

Reducing carbon emissions in Romania

There were 196 scientific articles found in the field of "carbon emissions", most of which are from between 2018 and 2019, with interest in this topic being seen each year. As you can see in Figure 1, the number of scientific articles on this topic has been relatively consistent over the last years.

The scientific papers dealing with topics related to the reduction of carbon emissions in Romania have identified several challenges and potential problems in this regard, synthesized under Table 4 .

Table 4. Synthesis of the main challenges and potential problems identified in the reduction of carbon emissions in Romania.

\begin{tabular}{|c|c|}
\hline Topics & Challenges and Potential Problems \\
\hline Photovoltaic energy & High costs of investing in photovoltaic panels \\
\hline Wind energy & High costs of investing in wind systems \\
\hline External energy audit & Energy audits are generally done only by big companies. \\
\hline Tax system & $\begin{array}{l}\text { Even if tax reliefs are granted for technological modernization, sometimes cheap traditional } \\
\text { technologies are preferred, which leads to the increase of carbon emissions. }\end{array}$ \\
\hline Human capital & Romania has the lowest score among the European Union member states \\
\hline Afforestation & $\begin{array}{l}\text { There are no platforms and programs for training in forestry aimed at the civil society and } \\
\text { children in particular }\end{array}$ \\
\hline Labor force & $\begin{array}{l}\text { Lack of occupational standards adapted to the current situation, especially in the fields of } \\
\text { agriculture and forestry. }\end{array}$ \\
\hline The COVID-19 pandemic & $\begin{array}{l}\text { The decrease in population mobility, telework, online sales have led to the reduction of } \\
\mathrm{CO}_{2} \text { emissions }\end{array}$ \\
\hline
\end{tabular}


The tax system is especially important in an economy, and many times its reform has a positive impact on technological progress, but sometimes governments tend to prefer to invest in cheaper traditional technologies, which leads to an increase in carbon emissions, and not to green technologies [73]. Human capital, defined by the knowledge that people acquire, accelerates innovation, leading to a reduction of carbon emissions. Paper [74] carried out a study showing that Sweden and Finland have the highest human capital index, of 0.80, Holland is right behind Sweden and Finland with 0.79, while Bulgaria with 0.61 and Romania with 0.58 have the lowest score from the other countries of the European Union. According to Eurostat [75], Sweden registered in 2019 one of the smallest values of carbon emissions compared to the other countries in the EU, while Romania registered in the same year $427 \%$ more carbon emissions than Sweden. Against the background of the COVID-19 pandemic, in the first semester of 2020, Romania's $\mathrm{CO}_{2}$ emissions decreased by 2546 thousand tonnes, $9.03 \%$ [76] The factors that led to these reductions are correlated to the recommendations to work from home, the forced transition to telehealth and online education, the quick transition to online retail sale, the closure of shops and nonessential production, limiting the hospitality sector and the sharp decrease in population mobility [76] According to [44] the "carbon footprint diagnosis", together with the energy performance diagnosis and the external energy audit are quite rare and very rare, and they exist rather in connection to the size of the company.

According to [77] the common factor for increasing carbon emissions in average income countries such as Romania is thought to be consumption volume. Paper [73] conducted a study on energy efficiency, and Romania takes 22nd place out of 29 countries. One of the main issues encountered regarding the use of solar energy, which is considered zero carbon emission energy, is the investment costs for photovoltaic panels and storage systems that are still high, limiting their use on a large scale in residential buildings [78]. Following the governmental program to subsidize the installation of photovoltaic panels, they were approved for installation in over 10,000 households [79]. Another concern of the Romanian government is the reduction of carbon emissions resulting from cars. Over the last years, there were several government programs to incentivize the purchase of electric and hybrid vehicles, the value of the subsidies allocated in 2020 being EUR 40 million [80]. The reduction of carbon emissions by absorption requires afforestation programs and strategies. Through the national forestry strategy [26], Romania aims to increase the carbon absorption and storage capacity of forests.

Green technology in Romania

A search by the "green technology" topic in the Scopus database has identified 68 results. Most scientific articles identified focused on technological development in the context of green energies (solar energy, biofuels), green technologies for wastewater and agriculture.

The scientific papers dealing with topics related to green technologies in Romania have identified several challenges and potential problems in this regard, synthesized under Table 5.

Table 5. Synthesis of the main challenges and potential problems identified in the use of green technologies in Romania.

\begin{tabular}{ll}
\hline Topics & Challenges and Potential Problems \\
\hline Biofuels & Development and implementation of technologies to convert biomass into energy \\
Eco-innovation & Stimulating research and the development of new knowledge \\
Water management & The need to protect vulnerable areas against floods \\
Recovery of materials & The need to use technologies or biotechnologies for wastewater treatment and water reuse \\
\hline
\end{tabular}

Technological innovation in Romania is based on research and development of new knowledge, young, highly skilled workers, led by specialists with experience in various fields [81]. One challenge found by the literature in the field is that technology can be regarded as a bond for research and innovation rather than the focus of research [82]. 
Paper [83] has identified a high production of agricultural raw materials in the case of certain countries (France, Germany and Romania), while for others (Austria, Finland and Sweden) an abundance of forestry residues, elements that enable the development of biofuels. The direct result of using biofuels is a reduction in the use of fossil fuels, with negative effects on exhaust emissions. According to [58], thermal energy has great potential insured by agricultural biomass, including industrial or household biodegradable waste.

An interesting study conducted by [84] shows that most power plants in Romania use cogeneration, which means that they produce power and heat. Power is generally delivered to the national network, while heat is used internally, for central heating or other processes that require heat. Wood processing companies generate high quantities of wood waste, making them eligible for biomass energy production, while companies in the agri-food sector focus on biogas consumption. Paper [83] presents a few solutions for the development of biofuel production, such as support for advanced biomass collection and programs for the development of conversion technologies.

Social inclusion in Romania

A search by the "social inclusion" topic has identified 121 results, most articles (15) dating from 2015. However, there was an approximatively equal distribution of the number of scientific articles over the years, which reveals that the interest in this topic is relatively consistent.

The scientific papers dealing with topics related to social inclusion in Romania have identified several challenges and potential problems in this regard, synthesized under Table 6.

Table 6. Synthesis of the main challenges and potential problems identified regarding social inclusion in Romania.

\begin{tabular}{ll}
\hline Topics & Challenges and Potential Problems \\
\hline & $\begin{array}{l}\text { The danger of the disappearance of certain jobs as a result of digitalization; there is a need for } \\
\text { retraining courses for the affected individuals } \\
\text { Difficult access to technology and the Internet for certain vulnerable categories (the elderly, people } \\
\text { with small incomes, etc.) or from particularly remote areas }\end{array}$ \\
$\begin{array}{l}\text { Simplification of the procedures to set up a company } \\
\text { Labor market }\end{array}$ & $\begin{array}{l}\text { Harmonization between the skills acquired through study and the requirements of the labor market } \\
\text { The COVID-19 pandemic }\end{array}$ \\
& $\begin{array}{l}\text { Limitation of social activities } \\
\text { The work-life balance has consequences for professional performance and personal wellbeing }\end{array}$ \\
\hline
\end{tabular}

The main fields of interest were the creation of jobs, telework and harmonization between the competencies acquired by study and the requirements of the labor market.

Creativity and innovation are essential attributes that help intelligent and resilient enterprises in their fight to lead the market by creating new jobs, eco-innovation, and social inclusion [81].

The easiest way to create jobs is by setting up new businesses. The study [81] considers that Romania needs an easier process for setting up a company, more governmental support, as well as the improvement of the entrepreneurial culture. The pandemic has caused people to organize their homes for telework, which implies a limitation of social interaction, with negative consequences for the individual [85]. The paradox of telework, according to [86] is that two things happen at the same time-a positive influence on autonomy and the worklife balance and a negative influence on vital professional relationships and on career, with contradictory repercussions on the welfare of the individual. Telework transfers certain issues connected to the green economy for employees of organizations from the office to the individual: the management of waste produced by employees during work hours, transfer of energy consumption to employees, the consumption of other resources, etc. It is educational institutions that stimulate creativity and give the graduates the knowledge necessary for the labor market, contributing to a robust economy [86]. 
Rational consumption in Romania

A search by the "rational consumption" topic has identified 15 results. The presence of this topic is quite low in scientific articles in the reference period, for the time being, it seems not to be of much interest to the scientific community in Romania. Most articles are focused on the area of medicine (drug consumption), energy and nutrition.

The scientific papers dealing with topics related to rational consumption in Romania have identified several challenges and potential problems in this regard, synthesized under Table 7.

Table 7. Synthesis of the main challenges and potential problems identified regarding rational consumption in Romania.

\begin{tabular}{ll}
\hline Topics & Challenges and Potential Problems \\
\hline Attitude to rational consumption & $\begin{array}{l}\text { Highlighting the advantages of rational consumption, first of all for the individual, society } \\
\text { and the environment } \\
\text { Individual wellbeing }\end{array}$ \\
$\begin{array}{l}\text { Promoting a healthier lifestyle associated with rational consumption } \\
\text { Water consumption }\end{array}$ & $\begin{array}{l}\text { Identifying the factors that influence the efficiency of water use in agriculture } \\
\text { Correct estimate of the electricity production needed to prevent energy waste } \\
\text { Energy consumption }\end{array}$ \\
\hline
\end{tabular}

Paper [68] highlights the changes over the last years in the behavior of consumers in the population of EU countries from the perspective of sustainable consumption, by adopting a consumption of healthy foods, reducing energy consumption in households, rational use of water resources and by trying to reduce the waste generated in the household. The same author has shown that there was a decrease at the EU level in the quantity of waste generated in the households, which was also felt in Romania. Paper [87] presents a study on the welfare of the elderly associated with a healthier lifestyle, which also implies rational consumption, while paper [88] presents a study on perceptions about nutrition among the young and the way they choose food, trying to identify preferences for a healthy and rational diet. Paper [68] presents a study on the attitude of European citizens towards the impact that their consumption habits have on the environment and the measures they took in order to reduce that impact. Over the last years, there is a consumer tendency to focus on healthy diets, including safe high-quality foods and high content of nutritional compounds from unpolluted areas. As a result of growing demand for clean foods, the area for organic farming has increased in most EU member states, including in Romania [68]. The results of the study proposed by [89] show that individual attitudes to the consumption of organic fruits and vegetables are directly and positively influenced by the information that people have on the characteristics of organic products, their personal needs and motivations, but also by external influences.

Testing the hypotheses on the interdependence between the key topics

The correlation matrix in Table 8 was drawn up in order to check the strength of the connections between the key topics analyzed.

Table 8. Correlation matrix.

\begin{tabular}{|c|c|c|c|c|c|}
\hline Topic & $\begin{array}{c}\text { Waste } \\
\text { Management }\end{array}$ & Green Technology & Carbon Emissions & Social Inclusion & $\begin{array}{c}\text { Rational } \\
\text { Consumption }\end{array}$ \\
\hline Waste management & 1 & & & & \\
\hline Green technology & 0.579059 & 1 & & & \\
\hline Carbon emissions & 0.590909 & 0.796343 & 1 & & \\
\hline Social inclusion & 0.22093 & 0.369556 & 0.534998 & 1 & \\
\hline $\begin{array}{c}\text { Rational } \\
\text { consumption }\end{array}$ & 0.43968 & 0.099851 & 0.28357 & 0.38636 & 1 \\
\hline
\end{tabular}


According to the data in Table 8, there is a connection and a strong correlation between the "carbon emissions" and "green technology" topics (H1), identified by a Pearson correlation coefficient of 0.7963 , which means hypothesis $\mathrm{H} 1$ has been confirmed. An average correlation between the "green technology" and "waste management" topics (H2) $\left(\mathrm{r}_{-}(\mathrm{y} / \mathrm{x})=0.5791\right)$, between the "carbon emissions" and "waste management" topics (H6) $\left(r_{-}(y / x)=0.5909\right)$, respectively between the "social inclusion" and "carbon emissions" topics (H5), which means the hypotheses H2, H6, H5 have been confirmed. A moderate interdependence $r_{-}(y / x) \in[0.5 ; 0.75)$ is found between "social inclusion" and "waste management" (H7), "green technology" (H4), also between "rational consumption" and "social inclusion" (H8), which means hypotheses H4, H7, H8 have been confirmed. There is no connection over time between "rational consumption" and "green technology" - $\left(\mathrm{r}_{-}(\mathrm{y} / \mathrm{x})=0.0998\right)$, which means hypothesis $\mathrm{H} 3$ has not been confirmed. Between topics "rational consumption" and "waste management" we have a medium interdependence $\left(\mathrm{r}_{-} \mathrm{y} / \mathrm{x}=0.43968\right)$, which means the hypothesis $\mathrm{H} 9$ has been confirmed.

\section{Limitations and Directions for Development of the Research}

The exploratory study that was conducted only captures scientific articles that include statements regarding Romania in the context of a predefined set of key topics connected to the green economy. A more detailed, in-depth research, with more keywords might enable more refined scientific conclusions about the green economy, possibly without significant correlations, these being harder to identify and track. However, the topics that were analyzed are considered essential for the green economy and even the authors of the scientific articles analyzed consider them important for their research, entering them as keywords in the Scopus database.

Given that the authors of most scientific articles analyzed by the study come from the world of academia, as a vector of the society, this can be the engine of the process to implement sustainability, respectively for the green economy. In this sense, in the future, it would be interesting to analyze the interdependence between the study programs in this area of interest, and the structure of the curriculum. A sustainable university is an educational institution that gets actively involved, by virtue of its place and role, in the elaboration of environmental policies and contributes to environmental protection by adapting the curriculum to social and environmental needs and by the progress of scientific knowledge, as a result of the teaching and research activities. The implementation of this process entails a global effort in which not only the teaching staff and the students take part, but also the extended network of partner individuals and organizations of the universities, social communities, and non-governmental organizations, both at a national and international level. University sustainability implies coordination and management skills, participation, involvement and commitment in all university fields [90].

A subsequent direction for research considered is the role of and the context in which the Romanian scientific research on key topics related to the green economy is integrated into the European and global scientific research. To this end, an analysis was conducted using the software app VOSViewer, version 1.1.17. to identify the main connections between Romanian researchers and researchers from other countries with a scientific interest in the green economy. Using the VOSViewer app a map was made (Figure 3) that shows graphically the connections between researchers in Romania and those in the countries that show up most frequently in the scientific production analyzed by the Scopus database. Scientific documents with authors from more than 25 countries were ignored; the minimum number of scientific documents for one country to appear on the map: minimum five publications.

The map in Figure 3 mainly highlights the connections between Romanian researchers and those in the European Union, but also with researchers from the USA, UK or China. 


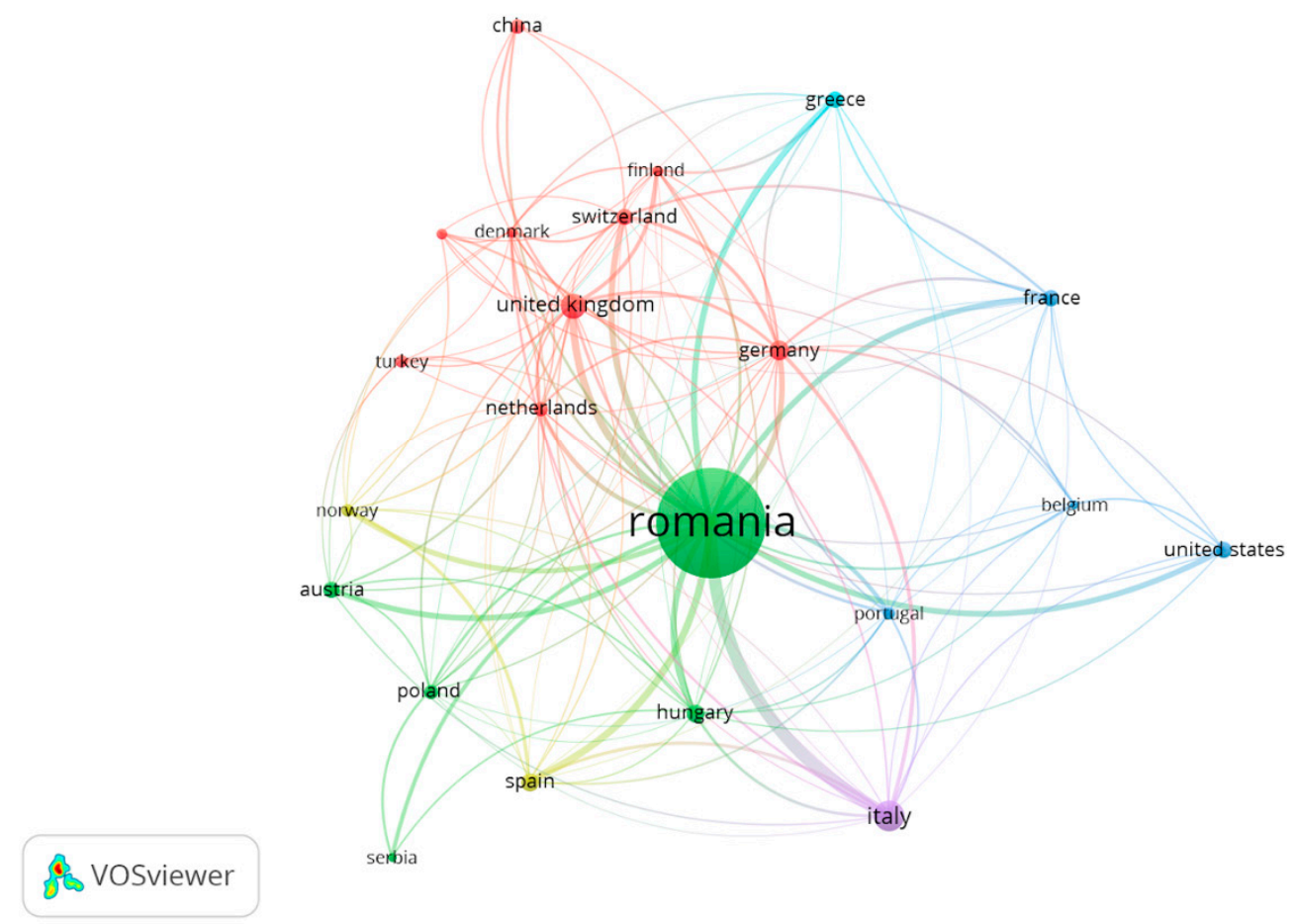

Figure 3. Graphical representation of the connections between researchers in Romania and those in the countries that show up most frequently in the scientific production analyzed. Source: processing done by the authors using VOSViewer, based on the data interrogated in the Scopus database.

\section{Conclusions}

A genuine shift in thinking about the green economy requires a creative approach that recognizes the different ways that people think and offers space for their ideas to develop. As a vector of the society, scientific research supports the progress of scientific knowledge resulting from research activities and becomes the engine of this process of implementing sustainability, respectively of the green economy.

The COVID-19 pandemic has also affected scientific production in the area of the green economy, 2020 registering a significant decrease in scientific articles, as seen from the research that was conducted. The pandemic has influenced all economic activities, in the direction of reducing them, also decreasing individual mobility, changing the general behavior of people and companies. Some areas related to the green economy, such as carbon emissions, have registered positive developments, but these are due rather to the reduction of economic activities caused by the limitations imposed by the pandemic and not to concrete significant actions in this direction.

The research we conducted highlights an increase in the scientific articles on topics related to waste management and reducing carbon emissions, which reveals a higher concern for these issues as opposed to others. These are also reflected in the Romanian law on the selective collection of waste and that on incentivizing the use of photovoltaic panels by the population or the purchase of electric/hybrid vehicles.

The pandemic has changed the way the green economy is perceived, telework has transferred certain issues related to the green economy from the companies to the employees. Waste management, energy and other resource consumption were transferred exclusively to the employees, who individually may or may not adopt environmental practices or in accordance with the policies of the green economy. Another issue that employees were faced with during the epidemic was the negative impact on social interactions, the welfare of the individual being affected. Individual consumption increase during the epidemic has led to an increase in the waste volume, and in some situations, due to working from home, we have noticed a transfer of the waste management issues from the organizations to the employees. One of the issues that Romania is facing is the 
low collection rate for waste electrical and electronic equipment, as well as the almost non-existent reuse rate.

The production of green energy resulting from biomass conversion has great potential due to the fact that Romania has a large agricultural area and implicitly a lot of agricultural raw materials, and that is needed is the development of the technologies required for biomass collection and conversion.

There is also a strong correlation between the "carbon emissions" and "green technology" topics revealed by the research conducted, which confirms the cause-and-effect relationship between the used technologies and carbon emissions, this being reflected in the literature from the analyzed period. As far as rational consumption is concerned, there is a general tendency towards a healthy diet, reducing energy consumption in households, rational use of water resources and reducing household waste. The research conducted does not reveal any connection between rational consumption and the other analyzed topics, which indicates as a possible explanation the fact that the topic of rational consumption somehow remains a behavior characteristic of the individual or the organization, influenced by other subjective factors.

Social inclusion as a goal of the green economy could be endangered by intensifying digitalization, as nowadays there is a tendency to increase computer skills and technical competencies. The concerns of the Romanian researchers in the field of social inclusion reached a peak in 2015 and focused predominantly on the creation of new jobs and telework. The connection between social inclusion and the other topics reveals average correlations with carbon emissions and waste management, the researchers being concerned about the impact of digitalization and telework on carbon emissions and waste management in the context of the technological progress in the last decade.

Although in Romania, as in many other countries, due to the COVID-19 pandemic there was a forced transition to a certain degree of digitalization, the lack of adequate digital infrastructure and the inertia of certain institutions was felt. These aspects caused a part of the principles and policies of the green economy to be lacking, both in terms of their regulation and their application. The lack of integrated platforms for the management of waste, green spaces and forests, etc., is noticeable, as perceived by the interested organizations and in the literature in the field.

Sustainable governance means active involvement in drawing up environmental policies and contributes to environmental protection by adapting to social and environmental needs. The implementation of this process entails a global effort in which not only the members of the organization take part, but also social communities and non-governmental organizations, both at a national and international level. In the context of sustainable development, the role of the educational institutions should be ex-tended from mediator between the requirements of the labor market and the research and development capabilities to harmonizer between creativity and innovation and the current challenges of the society and the economy, including references to the principles of the green economy in the curriculum. In order to achieve sustainable development within a sustainable green economy, organizations need to develop coordination and management skills, participation, involvement and commitment.

Author Contributions: F.M., O.E.A., E.G., C.D., M.G. were involved in the documentation phase, in choosing the research methodology, in data analysis, as well as in result analysis and discussions. F.M., O.E.A., E.G., C.D., M.G. participated in the manuscript preparation and have approved the submitted manuscript. All authors have read and agreed to the published version of the manuscript.

Funding: This research received no external funding.

Institutional Review Board Statement: Not applicable.

Informed Consent Statement: Not applicable.

Data Availability Statement: Data available on request due to restrictions.

Conflicts of Interest: The authors declare no conflict of interest. 


\section{References}

1. Gibbs, D. Green Economy. In International Encyclopedia of Human Geography; Elsevier: Amsterdam, The Netherlands, 2020; pp. 267-274. ISBN 978-0-08-102296-2.

2. Towards a Green Economy Pathways to Sustainable Development and Poverty Eradication. UNEP-UN Environment Programme. Available online: https://www.unep.org/resources/report/towards-green-economy-pathways-sustainabledevelopment-and-poverty-eradication-10 (accessed on 8 October 2021).

3. NGO. Education Committee Report of the World Commission on Environment and Development: Our Common Future. Available online: http:/ / www.eytv4scf.net/wced-ocf.htm (accessed on 8 October 2021).

4. Borel-Saladin, J.M.; Turok, I.N. The Green Economy: Incremental Change or Transformation? The Green Economy: Incremental Change or Transformation? Environ. Policy Gov. 2013, 23, 209-220. [CrossRef]

5. Ferguson, P. The Green Economy Agenda: Business as Usual or Transformational Discourse? Environ. Polit. 2015, $24,17-37$. [CrossRef]

6. Luederitz, C.; Abson, D.J.; Audet, R.; Lang, D.J. Many Pathways toward Sustainability: Not Conflict but Co-Learning between Transition Narratives. Sustain. Sci. 2017, 12, 393-407. [CrossRef]

7. D'Amato, D. Sustainability Narratives as Transformative Solution Pathways: Zooming in on the Circular Economy. Circ. Econ. Sustain. 2021, 1, 231-242. [CrossRef]

8. Pearce, D.; Markandya, A.; Barbier, E. Blueprint 1: For a Green Economy; Routledge: London, UK, 2013; ISBN 978-1-315-07022-3.

9. Folke, C.; Biggs, R.; Norström, A.V.; Reyers, B.; Rockström, J. Social-Ecological Resilience and Biosphere-Based Sustainability Science. Ecol. Soc. 2016, 21, art41. [CrossRef]

10. Dicționar Explicativ al Limbii Române. Dexonline. Available online: https:/ / dexonline.ro/ (accessed on 8 October 2021).

11. Barbier, E.B. The Green Economy Post Rio+20. Science 2012, 338, 887-888. [CrossRef]

12. Kazamias, G.; Zorpas, A.A. Drill Cuttings Waste Management from Oil \& Gas Exploitation Industries through End-of-Waste Criteria in the Framework of Circular Economy Strategy. J. Clean. Prod. 2021, 322, 129098. [CrossRef]

13. Agapios, A.; Andreas, V.; Marinos, S.; Katerina, M.; Antonis, Z.A. Waste Aroma Profile in the Framework of Food Waste Management through Household Composting. J. Clean. Prod. 2020, 257, 120340. [CrossRef]

14. Zorpas, A.A. Strategy Development in the Framework of Waste Management. Sci. Total Environ. 2020, 716, 137088. [CrossRef] [PubMed]

15. European Commission. The Environmental Implementation Review. 2019. Available online: https://ec.europa.eu/environment/ eir/pdf/report_ro_en.pdf (accessed on 8 October 2021).

16. Romanian Government. Romania's SUSTAINABLE DEVELOPMENT Strategy 2030. Available online: http:/ / dezvoltaredurabila gov.ro/web/wp-content/uploads/2019/03/Romanias-Sustainable-Development-Strategy-2030.pdf (accessed on 8 October 2021).

17. European Parliament Directive. 2012/19/EU of the European Parliament and of the Council of 4 July 2012 on Waste Electrical and Electronic Equipment (WEEE). Available online: https:/ / eur-lex.europa.eu/legal-content/EN/TXT/?uri=OJ\%3AL\%3A201 2\%3A197\%3ATOC (accessed on 13 November 2021).

18. European Parliament. Directive 2008/98/EC of the European Parliament and of the Council of 19 November 2008 on Waste and Repealing Certain Directives (Text with EEA Relevance). Available online: https:/ / eur-lex.europa.eu/legal-content/EN/TXT/ ?uri=celex:32008L0098 (accessed on 8 October 2021).

19. Systems, I. Ordonanța de Urgență nr. 74/2018 Pentru Modificarea și Completarea Legii nr. 211/2011 Privind Regimul Deșeurilor, a Legii nr. 249/2015 Privind Modalitatea de Gestionare a Ambalajelor și a Deșeurilor de Ambalaje și a Ordonanței de Urgență a Guvernului nr. 196/2005 Privind Fondul Pentru Mediu Actualizat. 2021. Available online: https:/ /lege5.ro/Gratuit/gi4dsmbxgqyq/ordonanta-de-urgenta-nr-74-2018-pentru-modificarea-si-completarea-legii-nr-2112011-privind-regimul-deseurilor-a-legii-nr-249-2015-privind-modalitatea-de-gestionare-a-ambalajelor-si-a-deseurilor-de-am (accessed on 8 October 2021).

20. European Parliament. European Parliament and Council Directive 94/62/EC of 20 December 1994 on Packaging and Packaging Waste. Available online: https:/ / eur-lex.europa.eu/legal-content/EN/TXT/?uri=OJ\%3AL\%3A1994\%3A365\%3ATOC (accessed on 13 November 2021).

21. European Parliament. Directive (EU) 2018/851 of the European Parliament and of the Council of 30 May 2018 Amending Directive 2008/98/EC on Waste (Text with EEA Relevance). Available online: https:/ / eur-lex.europa.eu/legal-content/en/TXT/ $\mathrm{PDF}$ / ?uri=CELEX:32018L0851\&from=EN (accessed on 8 October 2021).

22. European Parliament. Proposal for a REGULATION OF THE EUROPEAN PARLIAMENT AND OF THE COUNCIL Amending Regulation (EU) 2019/631 as Regards Strengthening the CO2 Emission Performance Standards for New Passenger Cars and New Light Commercial Vehicles in Line with the Union's Increased Climate Ambition COM/2021/556 Final. Available online: https:/ / eur-lex.europa.eu/legal-content/EN/TXT/?uri=CELEX\%3A52021PC0556 (accessed on 13 November 2021).

23. Romanian Environment Fund Administration. Electric Vehicle Charging Stations Program. Available online: https://www.afm. ro/statii_reincarcare_comunicate_2016_2019.php (accessed on 13 November 2021).

24. Romanian Environment Fund Administration. Non-Polluting Public Transport. Available online: https://www.afm.ro/ transport_public_nepoluant_comunicate.php (accessed on 13 November 2021).

25. European Commission. European Green Deal. Available online: https:/ / ec.europa.eu/info/strategy/priorities-2019-2024/ european-green-deal/delivering-european-green-deal_en (accessed on 13 November 2021). 
26. The Government of Romania. National Forest Strategy. Available online: http://www.mmediu.ro/app/webroot/uploads / files/ 2017-10-27_Strategia_forestiera_2017.pdf (accessed on 8 October 2021).

27. Romanian Environment Fund Administration. Energy Efficient House. Available online: https://www.afm.ro/casa_eficienta_ energetic.php (accessed on 13 November 2021).

28. Romanian Environment Fund Administration. Energy Efficiency in Public Buildings. Available online: https://www.afm.ro/ eficienta_energetica_cladiri_publice.php (accessed on 13 November 2021).

29. Romanian Environment Fund Administration. Classic Green House. Available online: https://www.afm.ro/casa_verde.php (accessed on 13 November 2021).

30. Romanian Environment Fund Administration. Photovoltaic Green House. Available online: https://www.afm.ro/sisteme_ fotovoltaice.php (accessed on 13 November 2021).

31. European Parliament. The Eco-Innovation Action Plan (Eco-AP). Available online: https://eur-lex.europa.eu/legal-content/EN/ ALL/? uri=CELEX\%3A52011DC0899 (accessed on 13 November 2021).

32. European Commission. Open Data Portal for the European Structural Investment Funds-European Commission. Data European Structural and Investment Funds. Available online: https://cohesiondata.ec.europa.eu/themes/9 (accessed on 13 November 2021).

33. European Parliament. A New Circular Economy Action Plan. Available online: https:/ / eur-lex.europa.eu/legal-content/EN/ TXT/?uri=COM\%3A2020\%3A98\%3AFIN (accessed on 13 November 2021).

34. European Parliament. New Consumer Agenda. Available online: https://eur-lex.europa.eu/legal-content/EN/TXT/?uri= CELEX\%3A52020DC0696 (accessed on 13 November 2021).

35. EY Romania. EY Attractiveness Survey Romania. Available online: https://assets.ey.com/content/dam/ey-sites/ey-com/ro_ ro/news/2021/ey_attractiveness_survey_en.pdf (accessed on 8 October 2021).

36. Loiseau, E.; Saikku, L.; Antikainen, R.; Droste, N.; Hansjürgens, B.; Pitkänen, K.; Leskinen, P.; Kuikman, P.; Thomsen, M. Green Economy and Related Concepts: An Overview. J. Clean. Prod. 2016, 139, 361-371. [CrossRef]

37. Lorek, S.; Spangenberg, J.H. Sustainable Consumption within a Sustainable Economy-Beyond Green Growth and Green Economies. J. Clean. Prod. 2014, 63, 33-44. [CrossRef]

38. Yoshino, N.; Taghizadeh-Hesary, F.; Nakahigashi, M. Modelling the Social Funding and Spill-over Tax for Addressing the Green Energy Financing Gap. Econ. Model. 2019, 77, 34-41. [CrossRef]

39. Lockwood, M. The Political Dynamics of Green Transformations: Feedback Effects and Institutional Context. In The Politics of Green Transformations; Routledge: Oxfordshire, UK, 2015; pp. 86-101.

40. Licastro, A.; Sergi, B.S. Drivers and Barriers to a Green Economy. A Review of Selected Balkan Countries. Clean. Eng. Technol. 2021, 4, 100228. [CrossRef]

41. Schimmelfennig, F.; Sedelmeier, U. Governance by Conditionality: EU Rule Transfer to the Candidate Countries of Central and Eastern Europe. J. Eur. Public Policy 2004, 11, 661-679. [CrossRef]

42. Florea, N.V.; Duică, M.C.; Ionescu, C.A.; Duică, A.; Ibinceanu, M.C.O.; Stanescu, S.G. An Analysis of the Influencing Factors of the Romanian Agricultural Output within the Context of Green Economy. Sustainability 2021, 13, 9649. [CrossRef]

43. Watson, M. Protecting the Environment: The Role of Environmental Management Systems. J. R. Soc. Promot. Health 2006, 126, 280-284. [CrossRef]

44. Maniu, I.; Costache, C.; Dumitraşcu, D.-D. Adoption of Green Environmental Practices in Small and Medium-Sized Enterprises: Entrepreneur and Business Policies Patterns in Romania. Sustainability 2021, 13, 4968. [CrossRef]

45. Baldé, C.P.; Forti, V.; Gray, V.; Kuehr, R.; Stegmann, R. The Global E-Waste Monitor, Quantities, Flows and Resources; United Nations University: Tokyo, Japan, 2017; pp. 1-10.

46. Gavrilescu, D.; Enache, A.; Ibănescu, D.; Teodosiu, C.; Fiore, S. Sustainability Assessment of Waste Electric and Electronic Equipment Management Systems: Development and Validation of the SUSTWEEE Methodology. J. Clean. Prod. 2021, 306, 127214. [CrossRef]

47. European Environment Agency. Waste Recycling in Europe-European Environment Agency. Available online: https://www. eea.europa.eu/data-and-maps/indicators/waste-recycling-2/assessment (accessed on 13 November 2021).

48. Mohsin, M.; Taghizadeh-Hesary, F.; Panthamit, N.; Anwar, S.; Abbas, Q.; Vo, X.V. Developing Low Carbon Finance Index: Evidence from Developed and Developing Economies. Financ. Res. Lett. 2020, 43, 101520. [CrossRef]

49. Mohsin, M.; Nurunnabi, M.; Zhang, J.; Sun, H.; Iqbal, N.; Iram, R.; Abbas, Q. The Evaluation of Efficiency and Value Addition of IFRS Endorsement towards Earnings Timeliness Disclosure. Int. J. Finance Econ. 2021, 26, 1793-1807. [CrossRef]

50. Asim, Z.; Sorooshian, S. Exploring the Role of Knowledge, Innovation and Technology Management (KNIT) Capabilities That Influence Research and Development. J. Open Innov. Technol. Mark. Complex. 2019, 5, 21. [CrossRef]

51. Mohsin, M.; Zhang, J.; Saidur, R.; Sun, H.; Sait, S.M. Economic Assessment and Ranking of Wind Power Potential Using Fuzzy-TOPSIS Approach. Environ. Sci. Pollut. Res. 2019, 26, 22494-22511. [CrossRef] [PubMed]

52. European Parliament. Reducing Carbon Emissions: EU Targets and Measures. News. Available online: https://www.europarl. europa.eu/news/en/headlines/society/20180305STO99003/reducing-carbon-emissions-eu-targets-and-measures (accessed on 13 November 2021).

53. Howson, P. Tackling Climate Change with Blockchain. Nat. Clim. Change 2019, 9, 644-645. [CrossRef] 
54. Howson, P. Building Trust and Equity in Marine Conservation and Fisheries Supply Chain Management with Blockchain. Mar. Policy 2020, 115, 103873. [CrossRef]

55. Goldstein, B.; Newell, J.P. How to Track Corporations across Space and Time. Ecol. Econ. 2020, 169, 106492. [CrossRef]

56. Fouksman, E.; Klein, E. Radical Transformation or Technological Intervention? Two Paths for Universal Basic Income. World Dev. 2019, 122, 492-500. [CrossRef]

57. SEEDS: Economic Renaissance. Available online: https:/ /joinseeds.earth/ (accessed on 7 October 2021).

58. Camasoiu, C.; Caragea, N.; Cristea, A. A Green Economy and New Challenges In Romania; Working Papers 07; Ecological University of Bucharest: Bucharest, Romania, 2013.

59. Pantelitsa, L.; Irene, V.; Zorpas, A.A. Boosting Regulations Legislation Reliefs Regarding Environmental Management Systems in the Framework of EMAS and ISO 14001: Case Study of Cyprus. Int. J. Therm. Environ. Eng. 2018, 17, 19-27. [CrossRef]

60. Testa, F.; Rizzi, F.; Daddi, T.; Gusmerotti, N.M.; Frey, M.; Iraldo, F. EMAS and ISO 14001: The Differences in Effectively Improving Environmental Performance. J. Clean. Prod. 2014, 68, 165-173. [CrossRef]

61. Daddi, T.; Testa, F.; Frey, M.; Iraldo, F. Exploring the Link between Institutional Pressures and Environmental Management Systems Effectiveness: An Empirical Study. J. Environ. Manag. 2016, 183, 647-656. [CrossRef]

62. European Commission. European Semester Thematic Factsheet Social Inclusion. Available online: https://ec.europa.eu/info/sites/ default/files/file_import/european-semester_thematic-factsheet_social_inclusion_en_0.pdf (accessed on 21 September 2021).

63. Kitchin, R. Reframing, Reimagining and Remaking Smart Cities; SocArXiv: College Park, MD, USA, 2016.

64. Awasthi, A.K.; Hasan, M.; Mishra, Y.K.; Pandey, A.K.; Tiwary, B.N.; Kuhad, R.C.; Gupta, V.K.; Thakur, V.K. Environmentally Sound System for E-Waste: Biotechnological Perspectives. Curr. Res. Biotechnol. 2019, 1, 58-64. [CrossRef]

65. Chen, M.; Ogunseitan, O.A. Zero E-Waste: Regulatory Impediments and Blockchain Imperatives. Front. Environ. Sci. Eng. 2021, 15, 114. [CrossRef]

66. Blomsma, F.; Tennant, M. Circular Economy: Preserving Materials or Products? Introducing the Resource States Framework. Resour. Conserv. Recycl. 2020, 156, 104698. [CrossRef]

67. European Union. Resource Efficiency-A Business Imperative. Available online: https://ec.europa.eu/environment/resource_ efficiency/documents / factsheet_en.pdf (accessed on 21 September 2021).

68. Humă, C. Measuring Change in Consumers' Behaviour, from an Ecologist Point of View, in EU Countries. Qual. Life 2013, XXIV/2013, 353-372.

69. Mayring, P. Qualitative Content Analysis. Forum Qual. Soz. 2000, 1. [CrossRef]

70. Zirna, G.; Saru, D.; Mocanu, S. Sustainable Waste Management System. In Proceedings of the 2021 12th International Symposium on Advanced Topics in Electrical Engineering (ATEE), Bucharest, Romania, 25 March 2021; pp. 1-5.

71. Sercaianu, M.; Petrescu, F.; Aldea, M.; Oana, L.; Rotaru, G. Web-GIS Platform for Green Infrastructure in Bucharest. In Proceedings of the SPIE-The International Society for Optical Engineering, 3rd International Conference on Remote Sensing and Geoinformation of the Environment, Paphos, Cyprus, 16-19 March 2015.

72. Leal Filho, W.; Salvia, A.L.; Minhas, A.; Paço, A.; Dias-Ferreira, C. The COVID-19 Pandemic and Single-Use Plastic Waste in Households: A Preliminary Study. Sci. Total Environ. 2021, 793, 148571. [CrossRef] [PubMed]

73. Zhang, J.; Patwary, A.K.; Sun, H.; Raza, M.; Taghizadeh-Hesary, F.; Iram, R. Measuring Energy and Environmental Efficiency Interactions towards $\mathrm{CO}_{2}$ Emissions Reduction without Slowing Economic Growth in Central and Western Europe. J. Environ. Manag. 2021, 279, 111704. [CrossRef] [PubMed]

74. Çakar, N.D.; Gedikli, A.; Erdoğan, S.; Yıldırım, D.Ç. Exploring the Nexus between Human Capital and Environmental Degradation: The Case of EU Countries. J. Environ. Manag. 2021, 295, 113057. [CrossRef]

75. Eurostat. Air Emission Database. Air Emission Intensities by NACE Rev. 2 Activity. Available online: https://ec.europa.eu/ eurostat/databrowser/view/env_ac_aeint_r2/default/table?lang=en (accessed on 8 October 2021).

76. Andreoni, V. Estimating the European CO2 Emissions Change Due to COVID-19 Restrictions. Sci. Total Environ. 2021, 769, 145115. [CrossRef]

77. Jiang, M.; An, H.; Gao, X.; Jia, N.; Liu, S.; Zheng, H. Structural Decomposition Analysis of Global Carbon Emissions: The Contributions of Domestic and International Input Changes. J. Environ. Manag. 2021, 294, 112942. [CrossRef]

78. Așchilean, I.; Cobîrzan, N.; Bolboaca, A.; Boieru, R.; Felseghi, R. Pairing Solar Power to Sustainable Energy Storage Solutions within a Residential Building: A Case Study. Int. J. Energy Res. 2021, 45, 15495-15511. [CrossRef]

79. Environment Fund Administration. Comunicat Presa. Available online: https://www.afm.ro/main/programe/sisteme_ fotovoltaice/2020/comunicat_presa-casa_verde-publicare_liste_pf-2020_04_30.pdf (accessed on 8 October 2021).

80. EFA. Environment Fund Administration. Available online: https:/ / afm.ro/ (accessed on 8 October 2021).

81. Bucea-Manea-Țoniş, R.; Šević, A.; Ilić, M.P.; Bucea-Manea-Toniş, R.; Popović Šević, N.; Mihoreanu, L. Untapped Aspects of Innovation and Competition within a European Resilient Circular Economy. A Dual Comparative Study. Sustainability 2021, 13, 8290. [CrossRef]

82. Mulligan, M.; Douglas, C.; van Soesbergen, A.; Shi, M.; Burke, S.; van Delden, H.; Giordano, R.; Lopez-Gunn, E.; Scrieciu, A. Environmental Intelligence for More Sustainable Infrastructure Investment. In Proceedings of the Conference on Information Technology for Social Good, Rome, Italy, 9 September 2021; pp. 225-229. 
83. Di Gruttola, F.; Borello, D. Analysis of the EU Secondary Biomass Availability and Conversion Processes to Produce Advanced Biofuels: Use of Existing Databases for Assessing a Metric Evaluation for the 2025 Perspective. Sustainability 2021, 13, 7882. [CrossRef]

84. Cebrucean, D.; Ionel, I. Bioenergy in Romania-A Short Overview of Biomass and Biogas-Based Plants. In Proceedings of the European Biomass Conference and Exhibition Proceedings, Lisbon, Portugal, 27-30 May 2019; pp. 220-225. [CrossRef]

85. Miron, D.; Petcu, M.; David-Sobolevschi, I.; Cojocariu, R.C. A Muldimensional Approach of the Relationship Between Teleworking and Employees Well-Being-Romania During the Pandemic Generated by the SARS-CoV-2 Virus. Amfiteatru Econ. 2021, 23, 586-600. [CrossRef]

86. Sava, D.; Badulescu, A. Creative and Cultural Sector: Focus on Romania; Vision 2020; Sustainable Economic Development and Application of Innovation Management, 2018; pp. 2564-2572. Available online: https://www.researchgate.net/publication/3294 28528_Creative_and_cultural_sector_Focus_on_Romania (accessed on 8 October 2021).

87. Caciula, I.; Boscaiu, V.; Cooper, C. Prevalence and Correlates of Well-Being in a Cross-Sectional Survey of Older People in Romania Attending Community Day Facilities. Eur. J. Psychiatry 2019, 33, 129-134. [CrossRef]

88. Onete, B.; Voinea, L.; Dina, R.; Vlad, D.E. The Internet Behavior of Young People Related to Use of Social Media Regarding Nutritional Choice. Actual Probl. Econ. 2013, 2, 191-197.

89. Radulescu, V.; Cetina, I.; Cruceru, A.F.; Goldbach, D. Consumers' Attitude and Intention towards Organic Fruits and Vegetables: Empirical Study on Romanian Consumers. Sustainability 2021, 13, 9440. [CrossRef]

90. Cullingford, C.; Blewitt, J. The Sustainability Curriculum: The Challenge for Higher Education; Earthscan: London, UK, 2004; ISBN 978-1-85383-948-1. 